Tropical Journal of Pharmaceutical Research March 2020; 19 (3): 603-608

ISSN: $1596-5996$ (print); 1596-9827 (electronic) (C) Pharmacotherapy Group, Faculty of Pharmacy, University of Benin, Benin City, 300001 Nigeria.

\title{
Yangjing capsule attenuates cyclophosphamide-induced deficiency of testicular microcirculation in mice
}

\author{
Baofang Jin ${ }^{1 *}$, Weihang Dong², Dalin Sun ${ }^{1}$, Bin Cai ${ }^{1}$, Weimin Deng ${ }^{1}$, Yugui Cui ${ }^{3}$, \\ Yihan Jin', Li Tong ${ }^{2}$, Ping $\mathrm{Wu}^{2}$ \\ ${ }^{1}$ Andrology Department of Integrative Medicine, School of Medicine, Zhongda Hospital Southeast University, Nanjing 210009, \\ ${ }^{2}$ Medical College of Qinghai University, Xi'ning 810001, Qinghai, ${ }^{3}$ State Key Laboratory of Reproductive Medicine, Clinical \\ Center of Reproductive Medicine, First Affiliated Hospital with Nanjing Medical University, ${ }^{4}$ Center of Reproductive Medicine, \\ School of Medicine, Zhongda Hospital Southeast University, Nanjing 210009, Jiangsu, China
}

*For correspondence: Email: hexiking@126.com

Sent for review: 21 February 2019

Revised accepted: 28 February 2020

\begin{abstract}
Purpose: To explore the protective effects of Yangjing capsule (YC) on testicular microcirculation in a mouse model of deficiency of testicular microcirculation.

Methods: Immunohistochemistry was applied to determine the effects of $Y C$ on microvascular density of mice. The protein level of CD34 and vascular endothelial growth factor A (VEGF A) was measured by western blot. The viability of Testicular cell line (TM4 cells) was examined by CCK-8 assay.

Results: Histopathological changes demonstrated that $C P$-induced decrease of microvascular density of the mice was rescued by $Y C$ dose-dependently $(p<0.5)$. Western blot data showed that the protein levels of CD34 and VEGF A in CP group were significantly decreased, but dose-dependently increased by $Y C$, respectively, following co-administration of $C P+Y C$, compared with those in $C P$ group $(p<0.5)$. The results from CCK-8 assay showed that the cell viability of TM4 cells increased with the amount of $Y C$ administered, and that high concentrations of $Y C(0.1$ and $1 \mathrm{mg} / \mathrm{mL})$ showed significant effects $(p<$ 0.5). Moreover, YC showed little effect on VEGF A mRNA and protein expression in TM4 cells.

Conclusion: YC may be considered an alternative therapeutic agent for the management of testicular microcirculation disease. However, further studies are required to ascertain this.
\end{abstract}

Keywords: Yangjing Capsule, Testicular microcirculation, Cyclophosphamide, Vascular endothelial growth factor $A$

\begin{abstract}
This is an Open Access article that uses a fund-ing model which does not charge readers or their institutions for access and distributed under the terms of the Creative Commons Attribution License (http://creativecommons.org/licenses/by/4.0) and the Budapest Open Access Initiative (http://www.budapestopenaccessinitiative.org/read), which permit unrestricted use, distribution, and reproduction in any medium, provided the original work is properly credited.

Tropical Journal of Pharmaceutical Research is indexed by Science Citation Index (SciSearch), Scopus, International Pharmaceutical Abstract, Chemical Abstracts, Embase, Index Copernicus, EBSCO, African Index Medicus, JournalSeek, Journal Citation Reports/Science Edition, Directory of Open Access Journals (DOAJ), African Journal Online, Bioline International, Open-J-Gate and Pharmacy Abstracts
\end{abstract}

\section{INTRODUCTION}

Testicular microcirculation is featured with a high-amplitude vasomotion and a low capillary pressure [1]. It possesses a series of temporal variation for complicated physiologic or pathophysiologic disturbances [1-3]. Testicular microcirculation play key roles in transporting nutritive compounds and removal of cellular waste products in the testis [4-5]. Testicular tissue microcirculation had a close relationship with sperm production and sperm function [6-8]. Abnormal testicular microcirculation might cause male infertility, especially in those with weak sperm [9]. 
Vascular endothelial growth factor (VEGF) is crucial regulator of phenotypic behaviors of vascular endothelial cells [10]. VEGF participates in angiogenesis, and could stimulate growth and development of vascular endothelial cells [11]. VEGFA, as the most efficient angiogenic factor in the VEGF family, has a crucial effect on embryonic lethality [12]. The downregulation of VEGFA in vascular endothelial cells induced postnatal mortality for vascular degeneration, which suggested an important role of VEGFA in vascular homeostasis [13]. Moreover, depletion of VEGFA isoforms mediates the expression of apoptotic testicular genes in mice, induces subfertility, decreased the number of sperms [14]. Meanwhile, it is known that VEGFA is involved in the chemotherapy of breast cancer cells [15]. However, whether VEGFA participates in the effects of YC on CP induced deficiency of testicular microcirculation is still lacking.

Recently, traditional Chinese medicine (TCM) was shown to have a huge advantage in the treatment of male infertility [16]. Yangjing capsule (YC) is a type of TCM [17]. It plays key roles in stimulating kidney activity [18]. YC could increase the number of sperm and sperm vitality for patients with male infertility [19]. YC promotes testosterone progression via steroidogenic enzymes and mediates male infertility and sexual dysfunction [20]. In previous research, it was indicated that YC could promote sperm concentration and motility in infertile males [17]. In addition, the YC might enhance androgen synthesis and hormonal balance [18]. However, whether YC affect the expression of VEGFA protein and testicular microcirculation remains unclear.

In the present study, the roles of YC in CPinduced deficiency of testicular microcirculation and expression of VEGFA was investigated. These findings may provide a novel strategy for CP-mediated deficiency of testicular microcirculation.

\section{EXPERIMENTAL}

\section{Animals and treatments}

Adult male (8 - 10 weeks old) Balb/c mice (weighing $20 \pm 2 \mathrm{~g}$ ) were acquired from Model Animal Research Center of Nanjing University (Nanjing, China). This study was approved by the Research Ethics Committee of Nanjing Medical University, China (20160623). This study strictly observed the principles of the Guide for the Care and Use of Laboratory Animals (NIH Publication No. 80-23, revised 1985). The mice were then randomly classified into: control, cyclophosphamide (CP, Pude Mecicine, Nanjing, China), CP + YC with 3 different doses (630, 1260 , and $2520 \mathrm{mg} / \mathrm{kg}$ ), with 12 mice in each group. For the first 7 days, the mice in groups treated with $\mathrm{CP}$ were injected intraperitoneally with CP (50 mg/kg/day). In addition, mice in the YC treatment groups were intragastrically administered with YC $(630,1260$, and 2520 $\mathrm{mg} / \mathrm{kg} /$ day) for consecutive 30 days. The animals' general health was observed daily. Finally, the testes tissues were rapidly excised and weighed followed by storing in liquid nitrogen or applying for the isolation of RNA and protein.

\section{YC extraction and cell culture}

YC extract was obtained as described previously $[21,22]$. YC was extracted from Yinyanghuo, Muli, Wangbuliuxing ect., and diluted with 333 $\mathrm{mL}$ of distilled water. Then the compounds were ultrasonicly extracted for $45 \mathrm{~min}$. The supernatants were collected at $13,000 \mathrm{~g}$ at $4{ }^{\circ} \mathrm{C}$ for $30 \mathrm{~min}$ to $100 \mathrm{mg} / \mathrm{mL}$ of the crude herb.

TM4 cell lines were provided by ATCC (Rockville, MD, USA). Cells were incubated with DMEM, supplemented with $10 \%$ FBS and $1 \%$ penicillin/streptomycin in $5 \% \mathrm{CO}_{2}$ at $37^{\circ} \mathrm{C}$ for 24 h. Cells were subjected to $0,0.01,0.1$, and $1 \mathrm{mg} / \mathrm{mL} \mathrm{YC}$ in $5 \% \mathrm{CO}_{2}$ at $37^{\circ} \mathrm{C}$ for $24 \mathrm{~h}$. After the above different treatments, TM4 cells were collected for the use of the following experiment.

\section{Immunohistochemistry}

Testis were embedded in paraffin. The sections were cultured a citrate buffer. The sections were subjected to primary antibodies against CD34 (Dako, Glostrup, Denmark) and then to the secondary antibody. Thereafter, the slices were incubated with DAB. Immunostaining was confirmed with a light microscope (K5007, Dako).

\section{RNA extraction and quantitative real-time polymerase chain reaction (qRT-PCR) analysis}

Total RNAs were collected from tissues and reversely transcribed into cDNA with PrimeScript RT Master Mix. qRT-PCR was conducted as previously described [18]. The relative expression was determined with $2^{-\Delta \Delta C t}$ method. GAPDH acted as an internal control. The the sequences of the primers used were as followed: VEGFA, forward: 5'-ATCCAATCGAGACCC TGGTG-3' and reverse: 5'-ATCTCTCCTATGTG CTGGCC-3'; GAPDH, forward: 5'-TGGGCTAC CGTGTTCCATC-3' and reverse: 5'-AGGTTGGT GAAGAAGTCGCA-3'. 


\section{Western blot}

The testes tissues or cells were lyzed with RIPA lysis buffer. Protein was isolated by $12 \%$ SDSPAGE and moved onto PVDF membranes (Millipore) and incubated with specific antibodies for GAPDH (ab181602, 1: 10000, Abcam, USA), CD34 (ab81289, 1: 10000, Abcam, USA) and VEGFA (ab52917, 1: 10000, Abcam, USA) at $4^{\circ} \mathrm{C}$ overnight and then with secondary antibody (ab6721, 1: 5000, Abcam, USA). GAPDH served as loading control.

\section{Cell viability}

CCK-8 was conducted to determine the cell viability after treatment with $\mathrm{YC}(0.01,0.1$ and 1 $\mathrm{mg} / \mathrm{mL})$. Cells $\left(2 \times 10^{3}\right.$ cells/well) were plated into 96-well plates. After that, CCK-8 kit was supplemented with $10 \mu \mathrm{L}$ of CCK8 solution. The absorbance rate at the wavelength of $450 \mathrm{~nm}$ was determined with a microplate reader (Bio-Rad Laboratories, Inc.).

\section{Statistical analysis}

Data are presented as mean \pm standard deviation $(S D, n=3)$. Difference between various groups were determined with one-way ANOVA. $P<0.05$ was deemed statistically significant.

\section{RESULTS}

\section{Effect of YC on microvascular density in mice}

Testicular micro vessels were closely distributed in microtubules. As shown in Figure 1, compared with control group (Figure $1 \mathrm{~A}$ ), the intensity of CD34 staining in CP group was decreased (Figure $1 \mathrm{~B}$ ); compared with CP group, YC dosedependently (630, 1260 and $2520 \mathrm{mg} / \mathrm{kg}$ ) increased the intensity of CD34 staining in CP + $\mathrm{YC}$ groups (Figure 1C-E). In addition, the intensity of CD34 staining in $\mathrm{CP}+\mathrm{YC}$ group (2520 mg/kg) was similar with that of control group. A previous study suggested that immunoexpression of CD34 was used to analyze testicular microvascular density [23]. To further clarify the effects of $\mathrm{YC}$ on the microvascular density of the mice, we examined the expression of CD34 protein levels in each group of testicular tissues as well. The western blot result showed that CD34 protein level in control group was significantly lower; compared with CP group, YC dose-dependently $(630,1260$ and $2520 \mathrm{mg} / \mathrm{kg}$ ) increased the CD34 protein level in $\mathrm{CP}+\mathrm{YC}$ groups; in addition, the CD34 protein level in CP + YC group (2520 mg/kg) was similar with that of control group (Figure 2 A), which showed a protective role of $\mathrm{YC}$ in $\mathrm{CP}$ induced decrease of microvascular density of mice.

\section{Effect of YC on expression of VEGFA in mice testis}

The qRT-PCR results indicated that the expression of VEGFA in the CP group and control group was of no significant difference, which was paralelled with $Y C(630,1260$, and $2520 \mathrm{mg} / \mathrm{kg}$ ) treatment group (Figures $3 \mathrm{~A}$ ). Interestingly, western-blot results suggested that compared with control group, CP significantly decreased VEGFA protein levels, which were dose-dependently reversed by $\mathrm{YC}$ treatment, and the protein level of VEGFA in CP + YC group $(2520 \mathrm{mg} / \mathrm{kg}$ ) was similar with that of control group (Figure $3 \mathrm{~B}$ and $\mathrm{C}$ ).

\section{YC increased TM4 cell viability}

CCK-8 assay was performed to examine TM4 cell viability. At 48-hour post treatment of $\mathrm{YC}$ extract $(0.01,0.1$ and $1 \mathrm{mg} / \mathrm{mL})$, the cell viability of TM4 cells was increased in a dose-dependent manner, and high doses ( 0.1 and $1 \mathrm{mg} / \mathrm{mL})$ of YC significantly increased the cell viability (Figure 4).

\section{Effect of YC on expressions of VEGFA in TM4 cells}

When TM4 cells were treated with $\mathrm{YC}$ at different concentrations $(0.01,0.1$ and $1 \mathrm{mg} / \mathrm{mL}$ ), we examine the expression of VEGFA in TM4 cells. The mRNA expression level of VEGFA was not changed even with gradually increased concentration of YC (Figure $5 \mathrm{~A}$ ). Similarly, western blotting results indicated that VEGFA protein expressions were also not changed with the increase of the $Y C$ concentration (Figures $5 \mathrm{~B}$ and $\mathrm{C}$ ).

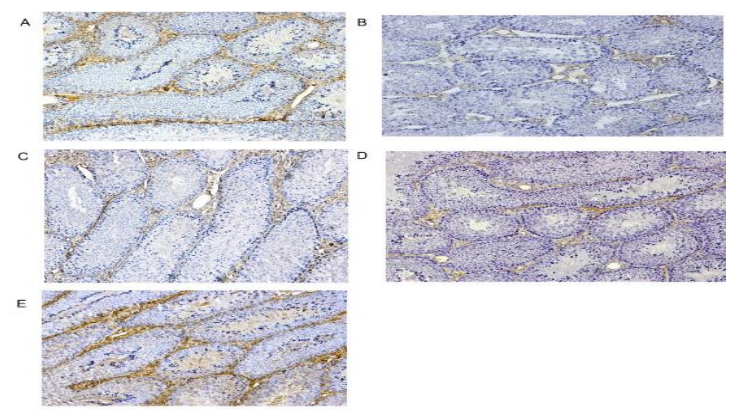

Figure 1: $Y C$ rescued $C P$ induced decrease of $C D 34$ staining in mice testis. The intensity of CD34 staining was lower in CP group (B) than in control group (A), which was increased dose-dependently by YC (630, 1260 and $2520 \mathrm{mg} / \mathrm{kg}$ ) (C - E) 


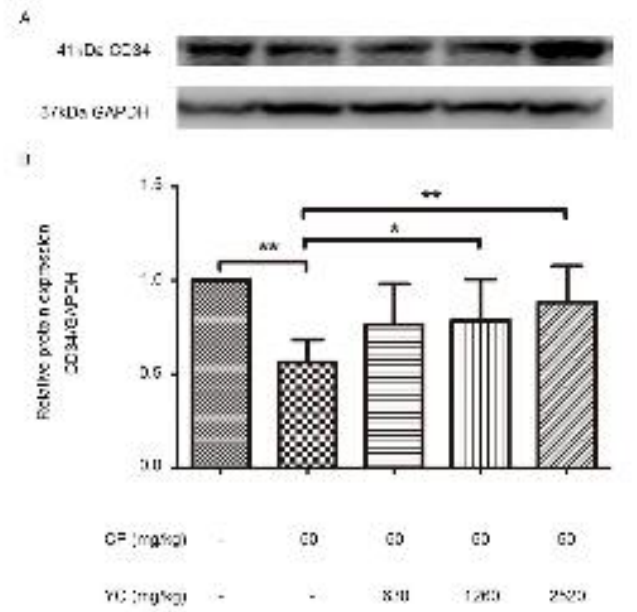

Figure 2: $Y C$ rescued $C P$ induced decrease of $C D 34$ protein level in mice testis. The protein level of CD34 was lower in CP group than in control group, which was increased dose-dependently by YC $(630,1260$ and $2520 \mathrm{mg} / \mathrm{kg}$ ) (A). The statistical data are also presented (B); ${ }^{*} p<0.05,{ }^{* *} p<0.01$

A
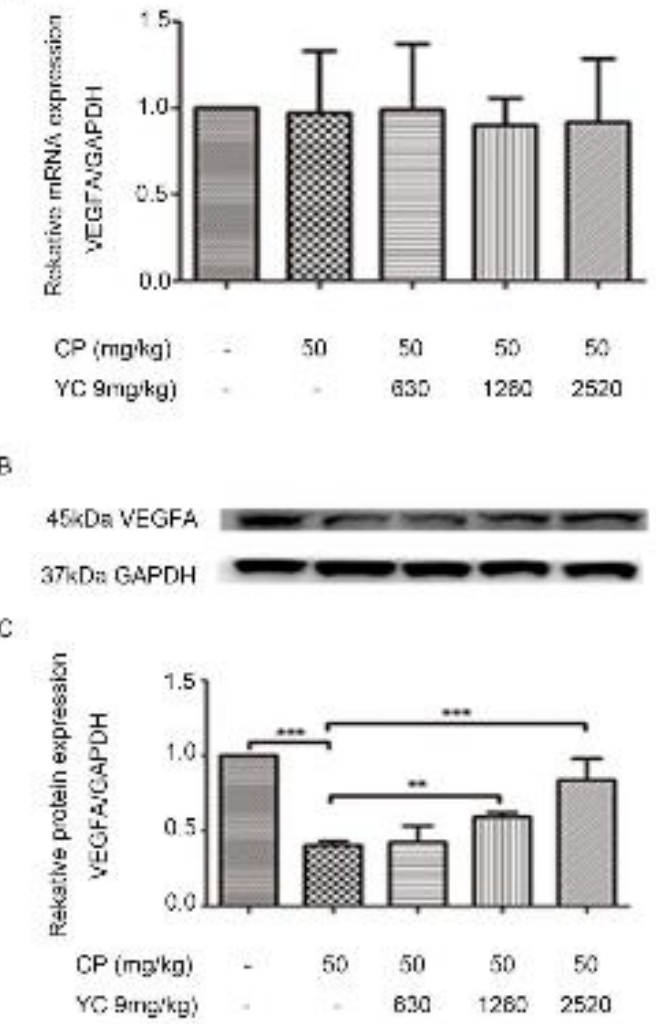

Figure 3: Effects of $Y C$ on the mRNA and protein level of VEGFA in mice testis. Neither CP nor YC affected the mRNA level of VEGFA (A). The protein level of VEGFA was lower in CP group than in control group, which was increased by $Y C(630,1260$ and 2520 $\mathrm{mg} / \mathrm{kg}$ ) in a dose-dependent manner (B and $\mathrm{C}$ ); ${ }^{* \star} p<$ 0.01

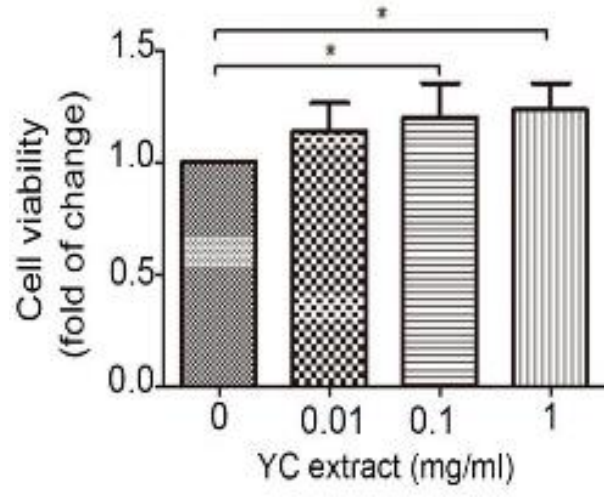

Figure 4: Effects of YC on TM4 cell viability. YC (0.01, 0.1 and $1 \mathrm{mg} / \mathrm{mL}$ ) improved the cell viability of TM4 in a concentration-dependent manner compared to control group.

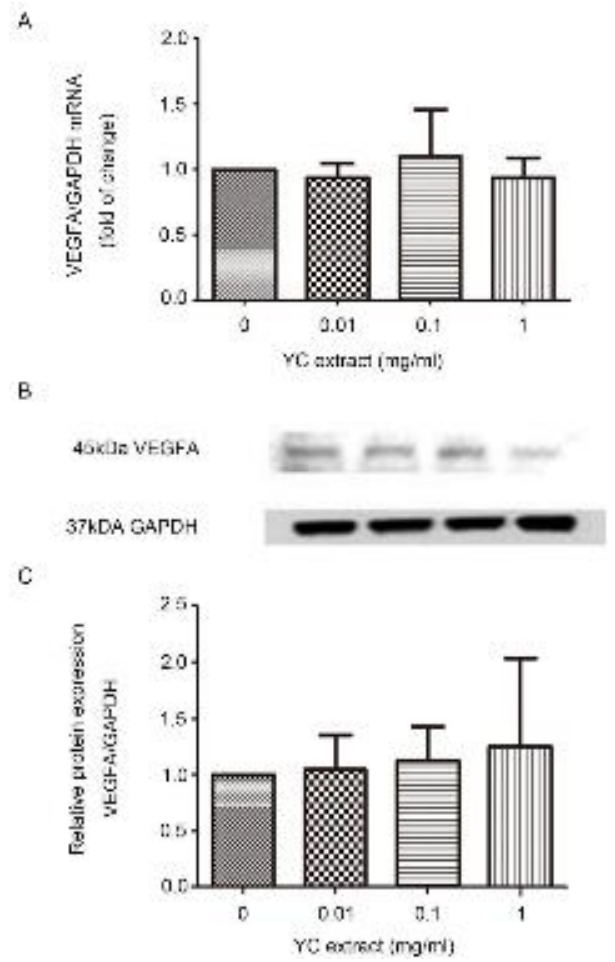

Figure 5: Effects of YC on VEGFA expression in TM4 cells. qRT-PCR suggested that the mRNA expression level of VEGFA was not changed with the treatment of YC (A). Similarly, western blotting results indicated that VEGFA protein expression changes were similar with that of mRNA (B and $C$ )

\section{DISCUSSION}

So far, low sperm count or poor motility and quality of sperm induced male infertility still affected male (24). Testicular microcirculation induced change of spermatogenesis is a common cause for male infertility [25]. Usually, infertile males are treated with hormones or

Trop J Pharm Res, March 2020; 19(3): 606 
empiric medical treatment, but the corresponding therapeutic effect is often not satisfactory [8]. Traditional Chinese formulations have achieved great advantages in the treatment of male infertility [17]. However, their molecular mechanisms of action on testicular microcirculation in infertile males remain unclear. In this study, we studied the roles of $Y C$ in testicular microcirculation in a mouse model whose dysregulation of testicular microcirculation was induced by CP.

Vascularization is an important part of microenvironment for the testis [4]. Increased microvessel density is a crucial factor in many physiologic and pathologic conditions [4]. In this study we found that administration of CP significantly decreased micro vessel density compared with the control group which was evidenced by decreased IHC staining for CD34 as well as decreased CD34 mRNA and protein levels. Interestingly, compared with $\mathrm{CP}$ group, YC significantly dose-dependently increased CD34 staining as well as in decreased CD34 $\mathrm{mRNA}$ and protein levels in testis sections of mice, indicating the protective effect of $\mathrm{YC}$ on micro vessel density and the development of blood vessels to improve testicular microcirculation in mice exposed to CP. The results are paralleled with Arena et al study [23].

In the current study, results indicated that VEGFA protein but not mRNA level was significantly decreased by $\mathrm{CP}$, which was significantly upregulated by $\mathrm{YC}$ in mice testis, suggesting the involvement of VEGFA in testicular microcirculation, which is consistent with Zhao et al study [20].

In addition, in this study, YC concentrationdependently increased the TM4 cell viability, suggesting that $\mathrm{YC}$ could promote the viability of TM4 cells in a concentration-dependent manner. Moreover, we found that VEGFA expression did not significantly changed the mRNA or protein level after treatment with different concentrations of $Y C$ in TM4 cells, indicating that $Y C$ alone had little effect on VEGFA expression in TM4 cells. Therefore, the $Y C$ exerted a beneficial effect on TM4 cells. The findings of YC in cells are consistent with $\mathrm{Gu}$ et al study, which revealed that YC stimulates testosterone synthesis [17].

Traditional Chinese medicine is drug mixture plays key role in in the treatment of male infertility via suppressing the progression of teratospermia and improving the sperm acrosin activity [16]. YC consisted of 11 traditional Chinese drugs [17]. Therefore, additional studies will be required to understand the pharmacological mechanisms of action of $\mathrm{YC}$ on the testes microenvironment in our future work.

In conclusion, the present study suggested that YC could rescue CP-induced decrease in the density of testicular microcirculation in male mice, which is likely due to the enhancement of TM4 cell viability. In addition, high expression of CD34 and VEGFA might be involved in the process of micro circulation in testis tissues, but YC had little effect on VEGFA expression in TM4 cells. Therefore, YC might be regarded as an alternative therapeutic treatment for testicular microcirculation in the future.

\section{DECLARATIONS}

\section{Acknowledgement}

This work was supported by grants from Chinese National Natural Science Foundation (nos. 81473678, 81874472 and 81603623).

\section{Conflict of interest}

No conflict of interest is associated with this work.

\section{Contribution of authors}

We declare that this work was done by the authors named in this article and all liabilities pertaining to claims relating to the content of this article will be borne by the authors. Baofang Jin provided the idea and prepared the manuscript; Weihang Dong, Dalin Sun, and Bin Cai collected materials; Weimin Deng, Yugui Cui, Yihan Jin, and $\mathrm{Li}$ Tong conducted the experiment and analyzed the data; Ping Wu corrected the manuscript.

\section{Open Access}

This is an Open Access article that uses a funding model which does not charge readers or their institutions for access and distributed under the terms of the Creative Commons Attribution License (http://creativecommons.org/licenses/by/ 4.0) and the Budapest Open Access Initiative (http://www.budapestopenaccessinitiative.org/rea d), which permit unrestricted use, distribution, and reproduction in any medium, provided the original work is properly credited.

\section{REFERENCES}

1. Bergh A, Lissbrant E, Collin O. Temporal variations in testicular microcirculatio. J Androl 1999; 20: 724-730.

Trop J Pharm Res, March 2020; 19(3): 607 
2. Collin O, Lissbrant E, Bergh A. Atrial natriuretic peptide, brain natriuretic peptide and c-type natriuretic peptide: effects on testicular microcirculation and immunohistochemical localization. Int J Androl 1997; 20: 55-60.

3. Collin O, Kilter S, Bergh A. Tobacco smoke disrupts testicular microcirculation in the rat. Int J Androl 1995, 18: 141-145.

4. Paul C, Rhind SM, Kyle CE, Scott H, McKinnell C, Sharpe RM. Cellular and hormonal disruption of fetal testis development in sheep reared on pasture treated with sewage sludge. Environ Health Perspect 2005; 113: $1580-1587$.

5. Chaki SP, Misro MM, Ghosh D, Gautam DK, Srinivas $M$. Apoptosis and cell removal in the cryptorchid rat testis. Apoptosis 2005; 10: 395-405.

6. Omid A, Ladan E, Reza K, Hemad SB, Mohammad R, Esmaili $N$, Faezeh $F$. The effects of long-term administration of tramadol on epididymal sperm quality and testicular tissue in mice. IJVS 2014; 9: 23-30.

7. Damber JE, Bergh A, Widmark A. Testicular blood flow and microcirculation in rats after treatment with ethane dimethyl sulfonate. Biol Reprod 1987; 37: 1291-1296.

8. Sadri-Ardekani $H$, Atala A. Testicular tissue cryopreservation and spermatogonial stem cell transplantation to restore fertility: from bench to bedside. Stem Cell Res Ther 2014; 5: 68.

9. Schurich M, Aigner F, Frauscher F, Pallwein L. The role of ultrasound in assessment of male fertility. Eur $\mathrm{J}$ Obstet Gynecol Reprod Biol 2009; 144: S192-S198.

10. Song $Y$, Song $Q, L i ~ L, X U$ J, Liu X. Effect of ranibizumab on levels of IL-6 and VEGF in peripheral blood and aqueous humor of glaucoma rat model and association of IL-6 and VEGF with optic nerve damage. Exp Ther Med 2018; 16: 2506-2510.

11. Hang TC, Tedford NC, Reddy RJ, Rimchala T, Wells A, White FM, Kamm RD, Lauffenburger DA. Vascular endothelial growth factor (VEGF) and platelet (PF-4) factor 4 inputs modulate human microvascular endothelial signaling in a three-dimensional matrix migration context. Mol Cell Proteomics 2013; 12: 37043718.

12. Li Y, Zhu $H$, Klausen $C$, Peng B, Leung PC. Vascular endothelial growth factor-A (VEGF-A) mediates activin A-induced human trophoblast endothelial-like tube formation. Endocrinol 2015; 156: 4257-4268.

13. Fan J, Ponferrada VG, Sato T, Vemaraju S, Fruttiger M, Gerhardt $H$, Ferrara N, Lang RA. Crim1 maintains retinal vascular stability during development by regulating endothelial cell Vegfa autocrine signaling. Development 2014; 141: 448-459

14. Lu N, Sargent KM, Clopton DT, Pohlmeier WE, Brauer VM, McFee RM, Weber JS, Ferrara N, Silversides DW,
Cupp AS. Loss of vascular endothelial growth factor $A$ (VEGFA) isoforms in the testes of male mice causes subfertility, reduces sperm numbers, and alters expression of genes that regulate undifferentiated spermatogonia. Endocrinol 2013; 154: 4790-4802.

15. Hu Y, Qiu Y, Yagüe E, Ji W, Liu J, Zhang J. miRNA-205 targets VEGFA and FGF2 and regulates resistance to chemotherapeutics in breast cancer. Cell Death Dis 2016; 7: e2291.

16. Hong GQ, Ding SZ, Chen CK. Clinical research of traditional Chinese medicine in the treatment of male infertility patients and sperm quality. China Practical Medicine, 2017.

17. Gu Y, Zhang X, Sun D, Zhao H, Cai B, Gao C, Gao L, Cui $Y$, Tang $Z$, Jin $B$. The stimulative effect of Yangjing capsule on testosterone synthesis through Nur77 pathway in leydig cells. Evid Based Complement Alternat Med 2015; 2015: 408686.

18. Sun $D$, Cui $Y$, Jin B, Zhang $X$, Yang $X$, Gao C. Effects of the Yangjing capsule extract on steroidogenesis and apoptosis in mouse leydig cells. Evid Based Complement Alternat Med 2012; 2012: 985457.

19. Wang Z, Jin B, Zhang $X$, Cui $Y$, Sun D, Gao C. Yangjing capsule extract promotes proliferation of GC-1 spg cells. Evid Based Complement Alternat Med 2014; 2014 : 640857.

20. Zhao $H$, Jin B, Zhang X, Cui $Y$, Sun D, Gao C, Gu Y, Cai $B$. Yangjing capsule ameliorates spermatogenesis in male mice exposed to cyclophosphamide. Evid Based Complement Alternat Med 2015; 2015: 980583.

21. Kao ST, Yeh CC, Hsieh CC, Yang MD, Lee MR, Liu HS, Lin JG. The Chinese medicine Bu-Zhong-Yi-Qi-Tang inhibited proliferation of hepatoma cell lines by inducing apoptosis via G0/G1 arrest. Life Sci 2001; 69: 14851496.

22. Hu B, An HM, Shen KP, Du Q. Effects of Tenglong Buzhong Decoction on proliferation and apoptosis of human colon carcinoma cell line LS174T. Zhong Xi Yi Jie He Xue Bao 2010; 8: 575-580.

23. Arena $S$, Minutoli L, Arena F, Nicotina PA, Romeo C, Squadrito $F$, Altavilla $D$, Morgia $G$, Magno $C$. Polydeoxyribonucleotide administration improves the intra-testicular vascularization in rat experimental varicocele. Fertil Steril 2012; 97: 165-168.

24. Anderson R, Moses R, Lenherr S, Hotaling JM, Myers J: Spinal cord injury and male infertility-a review of current literature, knowledge gaps, and future research. Transl Androl Urol 2018; 7: S373-S382.

25. Singh K, Jaiswal $D$ : One-carbon metabolism, spermatogenesis, and male infertility. Reprod Sci 2013; 20: 622 . 